\title{
Description of Spongiibacter borealis sp. nov., isolated from Arctic seawater, and reclassification of Melitea salexigens Urios et al. 2008 as a later heterotypic synonym of Spongiibacter marinus Graeber et al. 2008 with emended descriptions of the genus Spongiibacter and Spongiibacter marinus
}

\author{
Gwang II Jang, ${ }^{1 \dagger}$ Chung Yeon Hwang, ${ }^{1 \dagger}$ Han-Gu Choi, ${ }^{2}$ Sung-Ho Kang ${ }^{2}$ \\ and Byung Cheol Cho ${ }^{1}$
}

Correspondence

Byung Cheol Cho bccho@snu.ac.kr

\author{
${ }^{1}$ Microbial Oceanography Laboratory, School of Earth and Environmental Sciences and \\ Research Institute of Oceanography, Seoul National University, 599 Gwanak-ro, Gwanak-gu, \\ Seoul 151-742, Republic of Korea \\ ${ }^{2}$ Division of Polar Biology and Ocean Sciences, Korea Polar Research Institute, Get-Pearl Tower, \\ Songdo Technopark, 7-50 Songdo-dong, Yeonsu-gu, Incheon 406-840, Republic of Korea
}

\begin{abstract}
A Gram-negative, rod-shaped and motile strain, designated CL-AS9 ${ }^{\top}$, was isolated from polar seawater of the Arctic. Analysis of the 16S rRNA gene sequence of the strain showed an affiliation with the genus Spongiibacter, sharing $93.9 \%$ and $93.7 \%$ sequence similarities with the type strains of Spongiibacter tropicus CL-CB22 $1^{\top}$ and Spongiibacter marinus $\mathrm{HAL} 40 \mathrm{~b}^{\top}$, respectively. Phylogenetic analyses revealed that strain CL-AS9 ${ }^{\top}$ formed a separate branch that was distinct from a clade comprising Spongiibacter marinus $\mathrm{HAL} 4 \mathrm{bb}^{\top}$, Spongiibacter tropicus CL-CB221 ${ }^{\top}$

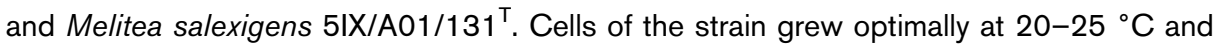
$\mathrm{pH} 6.6-8.0$ in the presence of 3-4\% (w/v) sea salts. The major polar lipids were diphosphatidylglycerol, phosphatidylglycerol and an unidentified aminophospholipid. The major quinone was ubiquinone 8 . The major cellular fatty acids were $\mathrm{C}_{16: 1} \omega 7 \mathrm{c}$ and/or iso- $\mathrm{C}_{15: 0} 2-\mathrm{OH}$ (23.1\%), $\mathrm{C}_{17: 1} \omega 8 c(22.1 \%)$ and $\mathrm{C}_{18: 1} \omega 7 c(15.6 \%)$. The genomic DNA G $+\mathrm{C}$ content was $53.6 \mathrm{~mol} \%$. Based on the phylogenetic, chemotaxonomic and phenotypic data presented, we propose the name Spongiibacter borealis sp. nov. with the type strain CL-AS9 ${ }^{\top}$ (=KCCM $90094^{\top}=\mathrm{JCM} 17304^{\top}$ ) and the reclassification of Melitea salexigens as a later heterotypic synonym of Spongiibacter marinus. We also provide emended descriptions of the genus Spongiibacter and Spongiibacter marinus.
\end{abstract}

The genus Spongiibacter in the class Gammaproteobacteria was established by Graeber et al. (2008) with Spongiibacter marinus as the type species. At the time of writing, two species of the genus Spongiibacter have been reported from marine environments: Spongiibacter marinus was isolated from a boreal sponge (Graeber et al., 2008) and Spongiibacter tropicus from a marine Synechococcus culture (Hwang \& Cho, 2009). Both species required $\mathrm{NaCl}$ for

†These authors contributed equally to this work.

The GenBank/EMBL/DDBJ accession number for the 16S rRNA gene sequence of strain CL-AS9 ${ }^{\top}$ is HQ199599.

A supplementary table and figure are available with the online version of this paper. growth (1-7\% and 1-9\% for Spongiibacter marinus and Spongiibacter tropicus, respectively) and had the same temperature range of 10 to $40{ }^{\circ} \mathrm{C}$ for growth (Graeber et al., 2008; Hwang \& Cho, 2009). The major fatty acids of the two species were $\mathrm{C}_{17: 1} \omega 8 c$ and $\mathrm{C}_{18: 1} \omega 7 c$ (Hwang \& Cho, 2009).

Eight months after the proposal of the genus Spongiibacter, the genus Melitea was proposed by Urios et al. (2008) with Melitea salexigens, a novel gammaproteobacterium isolated from sea surface layer. However, the close taxonomic relationship between the genera Spongiibacter and Melitea was not noticed until recently. During the present study, we recognized that Spongiibacter marinus $\mathrm{HAL}_{40 \mathrm{~b}}{ }^{\mathrm{T}}$ and Melitea salexigens 5IX/A0 $1 / 131^{\mathrm{T}}$ shared $99.2 \% 16 \mathrm{~S}$ rRNA 
gene sequence similarity. This similarity value is higher than the threshold of $97 \%$ (Rosselló-Mora \& Amann, 2001) or 98.7-99\% (Stackebrandt \& Ebers, 2006) above which DNA-DNA relatedness experiments should be mandatory for confirming separate species.

In this study, a marine bacterium was isolated and subjected to a polyphasic taxonomic analysis. In addition, Spongiibacter marinus $\mathrm{HAL}_{40 \mathrm{~b}^{\mathrm{T}}}$ and M. salexigens 5IX/ A01/131 ${ }^{\mathrm{T}}$ were compared using a polyphasic taxonomic approach to clarify the taxonomic positions of the two species.

Coastal seawater was collected near the Korean Arctic Dasan station at Svalbard in April 2010. An aliquot $(100 \mu \mathrm{l})$ of seawater was spread on various media including marine agar 2216 (MA, Difco) and incubated under aerobic conditions at $4-20{ }^{\circ} \mathrm{C}$ for a month. Among 56 colonies isolated and identified by $16 \mathrm{~S}$ rRNA gene sequencing (data not shown), only one strain (designated CL-AS9 ${ }^{\mathrm{T}}$ ) was affiliated with the genus Spongiibacter. Strain CL-AS9 ${ }^{\mathrm{T}}$ has been subsequently purified on fresh MA. Strain CL-AS9 ${ }^{\mathrm{T}}$ was maintained both on MA at $20{ }^{\circ} \mathrm{C}$ and in marine broth 2216 (MB, Difco) supplemented with $30 \%$ (v/v) glycerol at $-80{ }^{\circ} \mathrm{C}$.

For 16S rRNA gene amplification by PCR, DNA was extracted from a single colony by a boiling method (Englen \& Kelley, 2000). The crude extract served as the DNA template for PCR, which included Taq DNA polymerase (Bioneer) and primers 27F and 1492R (Lane, 1991). The PCR product was purified by using the AccuPrep PCR purification kit (Bioneer) and direct sequence determination of the purified 16S rRNA gene was performed using sequencing primers $(27 \mathrm{~F}, 518 \mathrm{~F}, 800 \mathrm{R}$ and 1492R; Lane, 1991; Anzai et al., 1997) with an Applied Biosystems automated sequencer (ABI3730XL) at Macrogen, Seoul, Korea. The almost complete $16 \mathrm{~S}$ rRNA gene sequence of strain CL-AS9 ${ }^{\mathrm{T}}$ (1429 bp) was obtained and compared with available 16S rRNA gene sequences in GenBank using BLASTN searches (Altschul et al., 1990). The 16S rRNA gene sequence of strain CL-AS9 ${ }^{\mathrm{T}}$ was aligned by the jPHYDIT program (Jeon et al., 2005) with the sequences of the type strains of other phylogenetically related species obtained from GenBank and Ribosomal Database Project II (Cole et al., 2007). Accurate multiple alignment was made manually according to the $16 \mathrm{~S}$ rRNA secondary structure information implemented in the jPHYDIT program. Phylogenetic trees were obtained by use of the neighbour-joining (Saitou \& Nei, 1987), maximum-parsimony (Fitch, 1971) and maximum-likelihood (Felsenstein, 1981) methods. An evolutionary distance matrix for the neighbour-joining method was generated according to the model of Jukes \& Cantor (1969). The robustness of tree topologies was assessed by bootstrap analyses based on 1000 replications for the neighbour-joining and maximum-parsimony methods and 100 replications for the maximum-likelihood method. Phylogenetic analyses were carried out using MEGA 4 (Tamura et al., 2007) and PAUP
4.0 (Swofford, 1998). Likelihood parameters were estimated by using the hierarchical ratio test in MODELTEST, version 3.04 (Posada \& Crandall, 1998).

Morphological and physiological tests were performed as follows. Gram-staining was performed as described by Smibert \& Krieg (1994). Unless otherwise specified, all biochemical characteristics of strain CL-AS9 ${ }^{\mathrm{T}}$ and Spongiibacter tropicus CL-CB22 $1^{\mathrm{T}}$ were based on cultures grown on MA at $25{ }^{\circ} \mathrm{C}$. Motility of the cells was assessed by the hanging drop method (Skerman, 1967) with cells grown in $\mathrm{MB}$ for 5 days. Cellular morphology and the presence of flagella were observed using transmission electron microscopy (EX2; JEOL). Anaerobic growth was checked on MA by using the GasPak anaerobic system (BBL) at $25{ }^{\circ} \mathrm{C}$ for 3 weeks. The temperature range for growth was examined on the basis of colony formation on MA incubated at $4{ }^{\circ} \mathrm{C}$ and temperatures ranging from 5 to $45{ }^{\circ} \mathrm{C}$, using increments of $5{ }^{\circ} \mathrm{C}$. The $\mathrm{pH}$ range ( $\mathrm{pH} 4.1-$ 9.9, using increments of approximately $1 \mathrm{pH}$ unit) for growth in $\mathrm{MB}$ was determined by assessing changes in optical density at a wavelength of $600 \mathrm{~nm}\left(\mathrm{OD}_{600}\right)$ over an incubation period of 10 days at $25{ }^{\circ} \mathrm{C}$; prior to autoclaving the medium, its $\mathrm{pH}$ was adjusted using $1 \mathrm{M} \mathrm{NaOH}$ and $1 \mathrm{M} \mathrm{HCl}$ solutions. Salt tolerance of strain CL-AS9 ${ }^{\mathrm{T}}$ was determined by assessing changes in $\mathrm{OD}_{600}$ in synthetic ZoBell broth (Bacto peptone, $5 \mathrm{~g}$; yeast extract, $1 \mathrm{~g}$; ferric citrate $0.1 \mathrm{~g}$; distilled water, $1 \mathrm{l}$ ) with varying concentrations $(0-10 \%$ in increments of $1 \%$, and $15 \%, w / v)$ of $\mathrm{NaCl}$ and sea salts (Sigma) at $25{ }^{\circ} \mathrm{C}$.

Oxidase and catalase tests were performed according to the protocols described by Smibert \& Krieg (1994). Hydrolysis of DNA, gelatin, starch and Tweens 40 and 80, ornithine and lysine deaminase activities, and Voges-Proskauer and methyl red tests were determined according to Hansen \& Sørheim (1991). $\mathrm{H}_{2} \mathrm{~S}$ production was tested as described by Bruns et al. (2001). In addition, other enzyme activities were assayed in duplicate using the API ZYM and API 20NE kits (bioMérieux) according to the manufacturer's instructions, except that the cell suspension was prepared using artificial seawater $\left(\mathrm{NaCl}, 24 \mathrm{~g} ; \mathrm{MgCl}_{2} .6 \mathrm{H}_{2} \mathrm{O}, 10.9 \mathrm{~g}\right.$; $\mathrm{Na}_{2} \mathrm{SO}_{4}, 4 \mathrm{~g} ; \mathrm{CaCl}_{2} .2 \mathrm{H}_{2} \mathrm{O}, 1.5 \mathrm{~g} ; \mathrm{KCl}, 0.7 \mathrm{~g} ; \mathrm{NaHCO}_{3}$, $0.2 \mathrm{~g} ; \mathrm{KBr}, 0.1 \mathrm{~g} ; \mathrm{H}_{3} \mathrm{BO}_{3}, 0.027 \mathrm{~g} ; \mathrm{SrCl}_{2} .6 \mathrm{H}_{2} \mathrm{O}, 0.03 \mathrm{~g}$; $\mathrm{NaF}, 0.003 \mathrm{~g}$; distilled water, 1 l; Lyman \& Fleming, 1940). Carbon utilization was tested using the basal broth medium supplemented with yeast extract $(\mathrm{NaCl}, 23.6$ g; $\mathrm{KCl}, 0.64 \mathrm{~g} ; \mathrm{MgCl}_{2} \cdot 6 \mathrm{H}_{2} \mathrm{O}, 4.53 \mathrm{~g} ; \mathrm{MgSO}_{4} \cdot 7 \mathrm{H}_{2} \mathrm{O}, 5.94 \mathrm{~g}$; $\mathrm{CaCl}_{2} \cdot 2 \mathrm{H}_{2} \mathrm{O}, 1.3 \mathrm{~g} ; \mathrm{NaNO}_{3}, 0.2 \mathrm{~g} ; \mathrm{NH}_{4} \mathrm{Cl}, 0.2 \mathrm{~g}$; yeast extract, $0.05 \mathrm{~g}$; distilled water, $1 \mathrm{l}$; Bruns et al., 2001) containing $0.4 \%$ carbon source. Growth was monitored by measuring $\mathrm{OD}_{600}$ using a spectrophotometer (Ultraspec 2000; Pharmacia Biotech) twice a week for approximately one month. Carbon utilization was scored as negative when growth rate was equal to or less than that in the negative control with no carbon source.

Polar lipids were extracted using the procedures described by Minnikin et al. (1984) and identified by two-dimensional 
TLC followed by spraying with appropriate detection reagents (Komagata \& Suzuki, 1987). The quinone system was determined according to Minnikin et al. (1984) and analysed by HPLC as described by Collins (1985) using Salinisphaera dokdonensis CL-ES53 ${ }^{\mathrm{T}}$ (Bae et al., 2010) as a reference strain. The fatty acid methyl esters in whole cells of strain CL-AS9 ${ }^{\mathrm{T}}$ grown on MA at $30{ }^{\circ} \mathrm{C}$ for 3 days were analysed by using gas chromatography according to the instructions of the Microbial Identification System (MIDI) at the Korean Culture Center of Microorganisms (KCCM) in Seoul, Korea. The genomic DNA G + C content of strain CL-AS9 ${ }^{\mathrm{T}}$ was analysed by HPLC (HP 100; Hewlett Packard) analysis of deoxyribonucleosides as described by Mesbah et al. (1989), after DNA was extracted by the method of Marmur (1961). Lambda phage DNA was used for calibration and the genomic DNA of Spongiibacter tropicus $\mathrm{CL}-\mathrm{CB} 221^{\mathrm{T}}$ as a reference.

To compare characteristics of Spongiibacter marinus HAL $40 \mathrm{~b}^{\mathrm{T}}$ and $M$. salexigens $5 \mathrm{IX} / \mathrm{A} 01 / 131^{\mathrm{T}}$, the following experiments were performed for both strains at the same time. Unless otherwise specified, all characteristics of Spongiibacter marinus $\mathrm{HAL}_{40 \mathrm{~b}^{\mathrm{T}}}$ and $M$. salexigens 5IX/ A01/131 ${ }^{\mathrm{T}}$ were based on cultures grown on MA at $30{ }^{\circ} \mathrm{C}$ for 3 days, and the same methods were employed as described above. Genomic DNA-DNA relatedness was determined by dot-blot hybridization (Kim et al., 2007). Pre-hybridization, hybridization (temperature of $45.8{ }^{\circ} \mathrm{C}$ ) and detection were performed by using a DIG labelling and detection kit (Roche Molecular Biochemicals) according to the manufacturer's instructions. The DNA-DNA hybridization experiment was repeated on two different days. Quinone system and polar lipids were determined as described above. Fatty acid methyl esters were analysed for cells of M. salexigens 5IX/A01/131 ${ }^{\mathrm{T}}$ grown on MA at $30{ }^{\circ} \mathrm{C}$ for 3 days, which were identical to conditions employed for fatty acid analysis of other species of the genus Spongiibacter (Hwang \& Cho, 2009; this study). Physiological tests (i.e. temperature, $\mathrm{pH}$ and $\mathrm{NaCl}$ ranges for growth) and all of the above biochemical tests were performed for Spongiibacter marinus $\mathrm{HAL}_{40 \mathrm{~b}}^{\mathrm{T}}$ and $M$. salexigens $5 \mathrm{IX} / \mathrm{A} 01 / 131^{\mathrm{T}}$.

Sequence analysis of the 16S rRNA gene showed that strain CL-AS9 ${ }^{\mathrm{T}}$ belonged to the class Gammaproteobacteria (Fig. 1). Strain CL-AS9 ${ }^{\mathrm{T}}$ was most closely related to Spongiibacter tropicus CL-CB221 ${ }^{\mathrm{T}}(93.9 \%$ similarity) and next to Spongiibacter marinus HAL40b ${ }^{\mathrm{T}}(93.7 \%$ similarity) and Melitea salexigens $5 \mathrm{IX} / \mathrm{A} 01 / 131^{\mathrm{T}}$ (93.7\% similarity); no other species in the class Gammaproteobacteria shared more than $92 \%$ sequence similarity with strain CL-AS9 ${ }^{\mathrm{T}}$.

Tree topologies inferred from three tree-making algorithms showed that strain CL-AS9 ${ }^{\mathrm{T}}$ formed a separate branch that was distinct from a clade (hereafter referred to as the Spongiibacter clade) comprising Spongiibacter tropicus, Spongiibacter marinus and M. salexigens (Fig. 1). Thus, the low sequence similarities (93.7-93.9\%) between strain CL-AS9 ${ }^{\mathrm{T}}$ and species with validly published names, and the phylogenetic position of strain CL-AS9 ${ }^{\mathrm{T}}$, indicated that our strain represents a novel species in the genus Spongiibacter.

The morphological, physiological and biochemical characteristics of strain CL-AS9 ${ }^{\mathrm{T}}$ are given in the species description and Table 1. The major fatty acids of strain CL$\mathrm{AS}^{\mathrm{T}}$ were summed feature $3\left(\mathrm{C}_{16: 1} \omega 7 c\right.$ and/or iso- $\mathrm{C}_{15: 0}$ 2-OH; $23.1 \%), \mathrm{C}_{17: 1} \omega 8 c(22.1 \%)$ and $\mathrm{C}_{18: 1} \omega 7 c(15.6 \%)$. The presence of a high amount of summed feature 3 and similar amounts of $\mathrm{C}_{17: 1} \omega 8 c$ and $\mathrm{C}_{18: 1} \omega 7 c$ could clearly differentiate strain CL-AS9 ${ }^{\mathrm{T}}$ from other species of the genus Spongiibacter and M. salexigens (Table 1). Other fatty acids of strain CL-AS9 ${ }^{\mathrm{T}}$ are shown in Supplementary Table S1 (available in IJSEM Online). The major polar lipids of strain CL-AS9 ${ }^{\mathrm{T}}$ were diphosphatidylglycerol, phosphatidylglycerol and an unidentified aminophospholipid (Supplementary Figure S1). The absence of two unidentified aminophospholipids (APL2 and APL4) could differentiate strain CL-AS9 ${ }^{\mathrm{T}}$ from Spongiibacter marinus and $M$. salexigens (Supplementary Figure S1). The genomic DNA $\mathrm{G}+\mathrm{C}$ content of strain $\mathrm{CL}-\mathrm{AS} 9^{\mathrm{T}}$ was $53.6 \mathrm{~mol} \%$, which

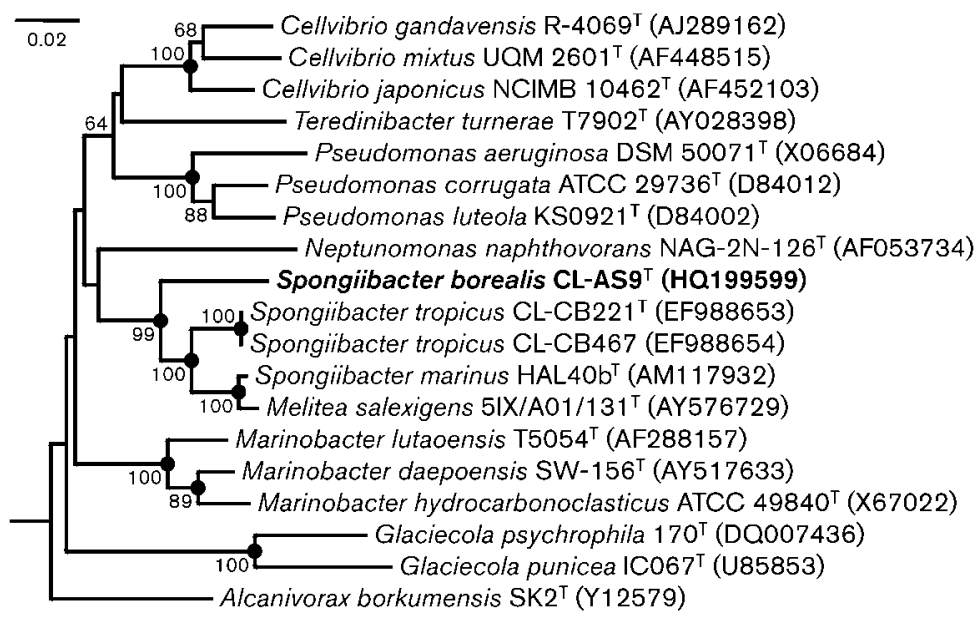

Fig. 1. Neighbour-joining tree showing the phylogenetic positions of strain CL-AS9 ${ }^{\top}$ and related members of the class Gammaproteobacteria on the basis of 16S rRNA gene sequence. Only bootstrap values above $60 \%$ are shown (1000 resamplings) at branching points. Solid circles indicate that the corresponding nodes were also obtained in the maximum-likelihood and maximum-parsimony trees. Thermotoga maritima MSB8 ${ }^{\top}$ (M21774) was used as an outgroup. Bar, 0.02 nucleotide substitutions per site. 
is lower $(>3.6 \mathrm{~mol} \%)$ than those of members of the Spongiibacter clade (Table 1).

Furthermore, strain CL-AS9 ${ }^{\mathrm{T}}$ can be differentiated from other species in the Spongiibacter clade by the ability to grow at $4-5{ }^{\circ} \mathrm{C}$, inability to grow at $35{ }^{\circ} \mathrm{C}$ or above and inability to grow in the presence of $\mathrm{NaCl}$ as sole salt (Table 1). Strain CL-AS9 ${ }^{\mathrm{T}}$ can be distinguished from Spongiibacter tropicus by the ability to hydrolyse Tween 40 . Strain CL-AS9 ${ }^{\mathrm{T}}$ can be distinguished from Spongiibacter marinus and M. salexigens by the inability to produce lipase $(\mathrm{C} 14)$ and leucine arylamidase, and the ability to utilize pyruvate as sole carbon source (Table 1).

To determine the taxonomic positions of Spongiibacter marinus $\mathrm{HAL}_{40 \mathrm{~b}^{\mathrm{T}}}$ and $M$. salexigens $5 \mathrm{IX} / \mathrm{A} 01 / 131^{\mathrm{T}}$, a polyphasic approach was employed. Phylogenetic analyses of $16 \mathrm{~S}$ rRNA gene sequences of both type strains revealed that they formed a robust clade within the genus Spongiibacter (Fig. 1) with a similarity of $99.2 \%$. This grouping was supported by high bootstrap values (neighbour-joining, $100 \%$; maximum-likelihood, $100 \%$; and maximum-parsimony, 99\%). The level of DNA-DNA relatedness between Spongiibacter marinus HAL40b $^{\mathrm{T}}$ and $M$. salexigens $5 \mathrm{IX} / \mathrm{A} 01 / 131^{\mathrm{T}}$ was $83 \pm 5 \%$ (reciprocal $85 \pm 0.4 \%)$, indicating that they belonged to the same species (Rosselló-Mora \& Amann, 2001). Fatty acid patterns were similar between Spongiibacter marinus $\mathrm{HAL}_{40 \mathrm{~b}^{\mathrm{T}}}$ and M. salexigens $5 \mathrm{IX} / \mathrm{A} 01 / 131^{\mathrm{T}}$ (Supplementary Table S1). The major quinone was ubiquinone $8(\mathrm{Q}-8)$. The major polar lipids were diphosphatidylglycerol, phosphatidylglycerol and unidentified aminophospholipid APL1 for both species (Supplementary Figure S1). Phenotypic characteristics were mostly identical (32 of 33 enzyme activities and 17 of 20 sole carbon source utilization) between Spongiibacter marinus HAL40b ${ }^{\mathrm{T}}$ and $M$. salexigens 5IX/A01/131 ${ }^{\mathrm{T}}$.

Overall, the phylogenetic, chemotaxonomic and phenotypic data obtained in this study indicate that strain CL$\mathrm{AS}^{\mathrm{T}}$ should be assigned to a novel species in the genus Spongiibacter, for which the name Spongiibacter borealis sp. nov. is proposed. In addition, it is proposed to unite the species Melitea salexigens Urios et al. 2008 and Spongiibacter marinus Graeber et al. 2008. According to Rules 38, 42 and $24 \mathrm{~b}(2)$ of the Bacteriological Code (Lapage et al., 1992), the name Spongiibacter marinus has

Table 1. Selected characteristics that differentiate strain CL-AS9 ${ }^{\top}$ from other species in the Spongiibacter clade

Strains: 1, CL-AS9 ${ }^{\mathrm{T}}$ (this study); 2, Spongiibacter tropicus CL-CB221 ${ }^{\mathrm{T}}$ (Hwang \& Cho, 2009); 3, Spongiibacter marinus HAL40b ${ }^{\mathrm{T}}$ (Graeber et al., 2008); 4, Melitea salexigens 5IX/A01/131 ${ }^{\mathrm{T}}$ (Urios et al., 2008). Fatty acids were analysed from cells grown on marine agar at $30{ }^{\circ} \mathrm{C}$ for 3 days (data for M. salexigens were obtained from this study). +, Positive; -, negative; w, weakly positive.

\begin{tabular}{|c|c|c|c|c|}
\hline Characteristic & 1 & 2 & 3 & 4 \\
\hline Isolation source & Arctic seawater & Synechococcus culture & Marine sponge & Seawater \\
\hline Temperature range for growth (optimum) $\left({ }^{\circ} \mathrm{C}\right)$ & $4-30(20-25)$ & $10-40(30-35)$ & $10-40(20-30)$ & $15-37(30)$ \\
\hline $\mathrm{pH}$ range for growth (optimum) & $5.8-9.3(6.6-8.0)$ & $6-10(7-8)$ & $6.5-9.5(7-9)$ & $6-10(8)$ \\
\hline Growth in the presence of $\mathrm{NaCl}$ as sole salt ${ }^{*}$ & - & + & + & + \\
\hline Hydrolysis of Tween $40^{\star}$ & + & - & + & + \\
\hline \multicolumn{5}{|l|}{ API ZYM test* } \\
\hline$N$-Acetyl- $\beta$-glucosaminidase & - & - & + & $-(w) \dagger$ \\
\hline Esterase $(\mathrm{C} 4)$ & + & $\mathrm{w}$ & + & $+(-) \dagger$ \\
\hline Leucine arylamidase & - & - & + & + \\
\hline Lipase (C14) & - & - & + & + \\
\hline \multicolumn{5}{|l|}{ Utilization of: ${ }^{*}$} \\
\hline Arabinose & - & - & + & - \\
\hline D-Glucose & - & - & + & $-(+) \dagger$ \\
\hline D-Mannose & $\mathrm{w}$ & - & + & $-(+) \dagger$ \\
\hline Pyruvate & + & + & - & - \\
\hline \multicolumn{5}{|l|}{ Major fatty acids (\%) } \\
\hline $\mathrm{C}_{16: 0}$ & 7.4 & $12.9-14.4$ & $3.2 \ddagger$ & 3.9 \\
\hline $\mathrm{C}_{17: 0}$ & 7.2 & $4.4-4.6$ & $11.2 \ddagger$ & 17.3 \\
\hline $\mathrm{C}_{17: 1} \omega 8 c$ & 22.1 & $14.7-15.3$ & $44.1 \ddagger$ & 35.8 \\
\hline $\mathrm{C}_{18: 1} \omega 7 c$ & 15.6 & $31.2-31.5$ & $6.8 \ddagger$ & 5.9 \\
\hline $\mathrm{C}_{11: 0} 3-\mathrm{OH}$ & 2.1 & $2.1-2.5$ & $6.3 \ddagger$ & 6.5 \\
\hline Summed feature $3\left(\mathrm{C}_{16: 1} \omega 7 c /\right.$ iso- $\left.\mathrm{C}_{15: 0} 2-\mathrm{OH}\right)$ & 23.1 & $11.4-12.5$ & $6.3 \ddagger$ & 4.8 \\
\hline DNA G $+C$ content $(\mathrm{mol} \%)$ & 53.6 & 57.7 & $69.1(60.6) \ddagger$ & 57.2 \\
\hline
\end{tabular}

${ }^{*}$ Data for Spongiibacter marinus HAL40b ${ }^{\mathrm{T}}$ and Melitea salexigens $5 \mathrm{IX} / \mathrm{A} 01 / 131^{\mathrm{T}}$ were obtained from this study.

$\dagger$ Data in parentheses are from Urios et al. (2008).

¥Data from Hwang \& Cho (2009). 
priority and hence should be used for the unified taxon, with Melitea salexigens as a later heterotypic synonym.

\section{Emended description of Spongiibacter Graeber et al. 2008}

The characteristics of the genus are as described by Graeber et al. (2008), with the following amendment. Motility is variable. The major polar lipids are diphosphatidylglycerol, phosphatidylglycerol and an unidentified aminophospholipid. The major quinone is Q-8.

\section{Emended description of Spongiibacter marinus Graeber et al. 2008}

The characteristics of the species are as described by Graeber et al. (2008) with the above modifications and the following amendment. Negative for hydrolysis of starch, DNA and gelatin. Negative for ornithine and lysine deaminase activities, Voges-Proskauer and methyl red tests. $\mathrm{H}_{2} \mathrm{~S}$ is not produced. According to the API ZYM test, $N$-acetyl- $\beta$ glucosaminidase activity is strain dependent. According to the API 20NE test, positive for aesculin hydrolysis, but negative for arginine dihydrolase, $\beta$-galactosidase (PNPG) and gelatinase, glucose fermentation, indole production, nitrate reductase and urease. Utilization of arabinose, D-glucose and D-mannose as sole carbon source is strain dependent, but acetate, L-arginine, cellobiose, citrate, D-fructose, D-galactose, glycerol, myo-inositol, lactose, mannitol, L-ornithine, pyruvate, L-rhamnose, D-salicin, sorbitol, succinate and xylose are not utilized. The minor polar lipids are three unidentified aminophospholipids. The G $+C$ content of DNA is $57.2-60.6 \mathrm{~mol} \%$.

\section{Description of Spongiibacter borealis sp. nov.}

Spongiibacter borealis (bo.re.a'lis. L. masc. adj. borealis related to the north, boreal).

Gram-negative, strictly aerobic, motile (by single polar flagellum), rods approximately $0.6-0.7 \mu \mathrm{m}$ wide and 1.3 $2.5 \mu \mathrm{m}$ long. After 5 days on marine agar plates at $25^{\circ} \mathrm{C}$, colonies are creamy, circular and convex, and approximately $1 \mathrm{~mm}$ in diameter. Grows at $4-30{ }^{\circ} \mathrm{C}$ (optimum $20-25{ }^{\circ} \mathrm{C}$ ) and $\mathrm{pH}$ 5.8-9.3 (optimum $\mathrm{pH}$ 6.6-8.0). No growth occurs in the presence of $\mathrm{NaCl}$ as sole salt. Growth occurs with 1-8\% (w/v) sea salts (optimum 3-4\%). Positive for oxidase and catalase. Tweens 40 and 80 are hydrolysed, but DNA, gelatin and starch are not. Negative for ornithine and lysine deaminase activities, Voges-Proskauer and methyl red tests. $\mathrm{H}_{2} \mathrm{~S}$ is not produced. According to the API ZYM test, positive for acid and alkaline phosphatases, esterase (C4), esterase lipase (C8) and naphthol-AS-BI-phosphohydrolase, but negative for $N$-acetyl- $\beta$-glucosaminidase, $\alpha$-chymotrypsin, cystine arylamidase, $\alpha$-fucosidase, $\alpha$ - and $\beta$-galactosidases, $\alpha$ - and $\beta$-glucosidases, $\beta$-glucuronidase, leucine arylamidase, lipase (C14), $\alpha$-mannosidase, trypsin and valine arylamidase. According to the API 20NE test, positive for aesculin hydrolysis, but negative for arginine dihydrolase, $\beta$-galactosidase
(PNPG) and gelatinase, glucose fermentation, indole production, nitrate reductase and urease. Pyruvate and D-mannose (weakly positive) are utilized as sole carbon source, but acetate, arabinose, L-arginine, cellobiose, citrate, D-fructose, D-galactose, D-glucose, glycerol, myo-inositol, lactose, mannitol, L-ornithine, L-rhamnose, D-salicin, sorbitol, succinate and xylose are not utilized. The major polar lipids are diphosphatidylglycerol, phosphatidylglycerol and an unidentified aminophospholipid. The minor polar lipids are two unidentified aminophospholipids. The major quinone is ubiquinone 8 . The major cellular fatty acids are $\mathrm{C}_{16: 1} \omega 7 c$ and/or iso- $\mathrm{C}_{15: 0} 2-\mathrm{OH}, \mathrm{C}_{17: 1} \omega 8 c$ and $\mathrm{C}_{18: 1} \omega 7 c$. The DNA G + C content of the type strain is $53.6 \mathrm{~mol} \%$.

The type strain, CL-AS9 ${ }^{\mathrm{T}}\left(=\mathrm{KCCM} 90094^{\mathrm{T}}=\mathrm{JCM} 17304^{\mathrm{T}}\right)$, was isolated from Arctic seawater.

\section{Acknowledgements}

We thank the expert technical support of Ms. In-Sung Lee (electron microscopy) of the National Center for Inter-University Research Facilities at Seoul National University. This work was supported by the KOPRI grant, by the MarineBio Technology Program funded by the Ministry of Land, Transport, and Maritime Affairs (MLTM), Korea (no. PE10060/PE11030), and by the BK21 project of the Korean Government.

\section{References}

Altschul, S. F., Gish, W., Miller, W., Myers, E. W. \& Lipman, D. J. (1990). Basic local alignment search tool. J Mol Biol 215, 403-410.

Anzai, Y., Kudo, Y. \& Oyaizu, H. (1997). The phylogeny of the genera Chryseomonas, Flavimonas, and Pseudomonas supports synonymy of these three genera. Int J Syst Bacteriol 47, 249-251.

Bae, G. D., Hwang, C. Y., Kim, H. M. \& Cho, B. C. (2010). Salinisphaera dokdonensis sp. nov., isolated from surface seawater. Int J Syst Evol Microbiol 60, 680-685.

Bruns, A., Rohde, M. \& Berthe-Corti, L. (2001). Muricauda ruestringensis gen. nov., sp. nov., a facultatively anaerobic, appendaged bacterium from German North Sea intertidal sediment. Int J Syst Evol Microbiol 51, 1997-2006.

Cole, J. R., Chai, B., Farris, R. J., Wang, Q., Kulam-Syed-Mohideen, A. S., McGarrell, D. M., Bandela, A. M., Cardenas, E., Garrity, G. M. \& Tiedje, J. M. (2007). The ribosomal database project (RDP-II): introducing $m y R D P$ space and quality controlled public data. Nucleic Acids Res 35 (Database issue), D169-D172.

Collins, M. D. (1985). Isoprenoid quinone analysis in classification and identification. In Chemical Methods in Bacterial Systematics, pp. 267-287. Edited by M. Goodfellow \& D. E. Minnikin. London: Academic Press.

Englen, M. D. \& Kelley, L. C. (2000). A rapid DNA isolation procedure for the identification of Campylobacter jejuni by the polymerase chain reaction. Lett Appl Microbiol 31, 421-426.

Felsenstein, J. (1981). Evolutionary trees from DNA sequences: a maximum likelihood approach. J Mol Evol 17, 368-376.

Fitch, W. M. (1971). Toward defining the course of evolution: minimum change for a specific tree topology. Syst Zool 20, 406-416.

Graeber, I., Kaesler, I., Borchert, M. S., Dieckmann, R., Pape, T., Lurz, R., Nielsen, P., von Döhren, H., Michaelis, W. \& Szewzyk, U. (2008). Spongiibacter marinus gen. nov., sp. nov., a halophilic marine 
bacterium isolated from the boreal sponge Haliclona sp. 1. Int J Syst Evol Microbiol 58, 585-590.

Hansen, G. H. \& Sørheim, R. (1991). Improved method for phenotypical characterization of marine bacteria. J Microbiol Methods 13, 231-241.

Hwang, C. Y. \& Cho, B. C. (2009). Spongiibacter tropicus sp. nov., isolated from a Synechococcus culture. Int J Syst Evol Microbiol 59, 2176-2179.

Jeon, Y.-S., Chung, H., Park, S., Hur, I., Lee, J.-H. \& Chun, J. (2005). jPHYDIT: a JAVA-based integrated environment for molecular phylogeny of ribosomal RNA sequences. Bioinformatics 21, 3171-3173.

Jukes, T. H. \& Cantor, C. R. (1969). Evolution of protein molecules. In Mammalian Protein Metabolism, vol. 3, pp. 21-132. Edited by H. N. Munro. New York: Academic Press.

Kim, Y.-G., Choi, D. H., Hyun, S. \& Cho, B. C. (2007). Oceanobacillus profundus sp. nov., isolated from a deep-sea sediment core. Int J Syst Evol Microbiol 57, 409-413.

Komagata, K. \& Suzuki, K. (1987). Lipids and cell-wall analysis in bacterial systematics. Methods Microbiol 19, 161-207.

Lane, D. J. (1991). 16S/23S rRNA sequencing. In Nucleic Acid Techniques in Bacterial Systematics, pp. 115-175. Edited by E. Stackebrandt \& M. Goodfellow. Chichester: Wiley.

Lapage, S. P., Sneath, P. H. A., Lessel, E. F., Skerman, V. B. D., Seeliger, H. P. R. \& Clark, W. A. (editors) (1992). International Code of Nomenclature of Bacteria (1990 Revision). Bacteriological Code. Washington, DC: American Society for Microbiology.

Lyman, J. \& Fleming, R. H. (1940). Composition of sea water. J Mar Res 3, 134-146.

Marmur, J. (1961). A procedure for the isolation of deoxyribonucleic acid from micro-organisms. J Mol Biol 3, 208-218.
Mesbah, M., Premachandran, U. \& Whitman, W. B. (1989). Precise measurement of the $\mathrm{G}+\mathrm{C}$ content of deoxyribonucleic acid by highperformance liquid chromatography. Int J Syst Bacteriol 39, 159-167.

Minnikin, D. E., O’Donnell, A. G., Goodfellow, M., Alderson, G., Athalye, M., Schaal, K. \& Parlett, J. H. (1984). An integrated procedure for the extraction of bacterial isoprenoid quinones and polar lipids. J Microbiol Methods 2, 233-241.

Posada, D. \& Crandall, K. A. (1998). MODELTEST: testing the model of DNA substitution. Bioinformatics 14, 817-818.

Rosselló-Mora, R. \& Amann, R. (2001). The species concept for prokaryotes. FEMS Microbiol Rev 25, 39-67.

Saitou, N. \& Nei, M. (1987). The neighbor-joining method: a new method for reconstructing phylogenetic trees. Mol Biol Evol 4, 406425.

Skerman, V. B. D. (1967). A Guide to the Identification of the Genera of Bacteria, 2nd edn. Baltimore: Williams \& Wilkins.

Smibert, R. M. \& Krieg, N. R. (1994). Phenotypic characterization. In Methods for General and Molecular Bacteriology, pp. 607-654. Edited by P. Gerhardt, R. G. E. Murray, W. A. Wood \& N. R. Krieg. Washington, DC: American Society for Microbiology.

Stackebrandt, E. \& Ebers, J. (2006). Taxonomic parameters revisited: tarnished gold standards. Microbiol Today 33, 152-155.

Swofford, D. L. (1998). Phylogenetic analysis using parsimony (PAUP), version 4. Sunderland, MA: Sinauer Associates.

Tamura, K., Dudley, J., Nei, M. \& Kumar, S. (2007). MEGA4: molecular evolutionary genetics analysis (MEGA) software version 4.0. Mol Biol Evol 24, 1596-1599.

Urios, L., Agogué, H., Intertaglia, L., Lesongeur, F. \& Lebaron, P. (2008). Melitea salexigens gen. nov., sp. nov., a gammaproteobacterium from the Mediterranean Sea. Int J Syst Evol Microbiol 58, 2479-2483. 